\title{
Az alsó ferde szemizom dozírozott transzpozíciójának hatásossága strabismus sursoadductorius esetén
}

\author{
Maneschg Otto Alexander dr. - Knézy Krisztina dr. - Maka Erika dr. \\ Benyó Fruzsina dr. - Sándor Gábor dr. - Nagy Zoltán Zsolt dr.
}

Semmelweis Egyetem, Általános Orvostudományi Kar, Szemészeti Klinika, Budapest

\begin{abstract}
Bevezetés: Az idiopathiás strabismus sursoadductorius jellemzője, hogy adductiós helyzetben a szemgolyó túlzottan felfelé áll, az alsó ferde külső szemizom túlmúködése miatt. Ennek következménye lehet krónikus fejfájás, szemfájdalom, kettôs képlátás és ferde fejtartás.

Célkitüzés: Strabismus sursoadductorius esetén a musculus obliquus inferior dozírozott transzpozícióját követő klinikai eredmények bemutatása.

Módszer: Retrospektív szemikvantitatív módszerrel vizsgáltuk azokat a betegeket ( 53 beteg), akiknél 6 éves periódusban (2012-2017) az alsó ferde szemizom dozírozott transzpozícióját végeztük a Semmelweis Egyetem Szemészeti Klinikáján. A betegek átlagéletkora 12,8 év (min.-max.: 2-5l év) volt. A szemizom transzpozícióját $(8 \mathrm{~mm} / 10 \mathrm{~mm} /$ maximális) az említett izom túlmúködése miatt a maximális adductióban mért vertikális deviáció (VD) függvényében végeztük. Maximális transzpozíció esetén az alsó ferde szemizom tapadását az alsó egyenes szemizom laterális széle elé helyeztük át. A kancsalsági szöget 5 tekintési irányban mértük meg a mútét előtt, valamint a műtét után 1 héttel, 1 hónappal és 3-6 hónappal. Meghatároztuk a betegek legjobb korrigált látóélességét, vizsgáltuk a betegek binokularitását és a mútét utáni szövődményeket.

Eredmények: A mútét után 25 betegnél volt elfogadható binokularitás (Titmus 5 ). A látóélesség minden esetben stabil maradt a posztoperatív időszakban. A maximális adductióban mért vertikális deviáció $8 \mathrm{~mm}$-es transzpozíció esetén $7,5^{\circ}$-kal, míg maximális transzpozíció esetén $12^{\circ}$-kal csökkent. Az első posztoperatív hét végén átlagosan 17,8 prizmadioptriával (PD) ( $<<0,01)$, az első hónap után 20,5 PD-val csökkent a VD, ami a mútét utáni 3-6 hónapos követési idő alatt tartósan stabil maradt.

Következtetés: Strabismus sursoadductorius esetén ajánlott mútéti eljárás az alsó ferde szemizom dozírozott transzpozíciója. A funkcionális alul- és túlkorrekció előfordulása alacsony.
\end{abstract}

Orv Hetil. 2019; 160(27): 1064-1069.

Kulcsszavak: strabismus sursoadductorius, az alsó ferde szemizom túlmúködése, dozírozott transzpozíció

\section{Results after graded recession of inferior oblique muscle in strabismus sursoadductorius}

Introduction: Idiopathic strabismus sursoadductorius is characterized by an overaction of the inferior oblique (IO) muscle, with elevation of the eye in adduction. This can result in chronic headache, eye pain, diplopia and abnormal head posture.

Aim: Presentation of clinical results after graded recession of inferior oblique overaction (IOOA) in strabismus sursoadductorius.

Method: During a period of 6 years (2012-2017) we performed a dosed transposition of IO muscle in 53 patients in the Department of Ophthalmology of the Semmelweis University and analyzed the clinical results retrospectively. The mean age was 12.8, min-max: 2-51 years. The transposition of the muscle $(8 \mathrm{~mm}, 10 \mathrm{~mm}$ or maximal $)$ was performed because of IOOA and was planned depending on the vertical deviation (VD) in maximal adduction. In case of maximal transposition, the insertion of IO was placed under the lateral part of the lower rectus muscle. We evaluated the squint angle in five positions of gaze preoperatively and postoperative 1 week, 1 month and 3-6 months. We examined best corrected visual acuity, binocular vision and complications after surgery.

Results: Postoperatively 25 patients had acceptable stereopsis (Titmus 5 ). Visual acuity remained stable after surgery in all cases. The VD measured in maximal adduction changed with a decrease of $7.5^{\circ}$ when $8 \mathrm{~mm}$ transposition was 
performed, and changed with a decrease to $12^{\circ}$, when maximal recession was performed. The mean reduction of VD was 17.8 prism dioptres (PD) after 1 week $(\mathrm{p}<0.01), 20.5 \mathrm{PD}$ after 1 month and remained stable during a follow-up of 3-6 months.

Conclusion: Graded recession of inferior oblique muscle is a suitable proposed procedure in patients with marked strabismus sursoadductorius. The rates of functional under- or overcorrection or other complications are low.

Keywords: strabismus sursoadductorius, inferior oblique overaction, inferior oblique recession

Maneschg OA, Knézy K, Maka E, Benyó F, Sándor G, Nagy ZZs. [Results after graded recession of inferior oblique muscle in strabismus sursoadductorius]. Orv Hetil. 2019; 160(27): 1064-1069.

(Beérkezett: 2019. február 19.; elfogadva: 2019. március 11.)

\section{Rövidítések}

$\mathrm{AHP}=($ abnormal head posture $)$ kényszerfejtartás; BCVA $=$ (best corrected visual acuity) legjobb korrigált látóélesség; BSV $=($ binocular single vision $)$ binokuláris látás; DVD $=$ (dissociat ed vertical deviation $)$ disszociált vertikális deviáció; $\mathrm{HD}=$ (horizontal deviation) horizontális deviáció; $\mathrm{IO}=$ (obliquus inferior) alsó ferde; IOOA = (inferior oblique overaction $)$ az alsó ferde szemizom túlmúködése; $\mathrm{IR}=$ (inferior rectus) alsó egyenes; $\mathrm{LR}=$ (lateral rectus) laterális egyenes; $\mathrm{MR}=$ (medial rectus) mediális egyenes; $\mathrm{PD}=$ (prism dioptre) prizmadioptria; $\mathrm{SO}=($ superior oblique $)$ felső ferde $; \mathrm{VD}=($ vertical deviation $)$ vertikális deviáció

Az idiopathiás (primer) strabismus sursoadductorius a kancsalság egyik típusa, melyet esotropia, adductiós helyzetben a szemgolyó túlzott felfelé állása (hypertropia) és excyclotropia jellemez. Lehet egy-, illetve kétoldali. Biomechanikai sajátossága az alsó ferde (IO) szemizom túlmúködése (IOOA) [1]. Az esotropiás betegek 70\%-ánál, az exotropiás betegek 30\%-ánál fordul elő IOOA [2]. Mindkét forma esetén megkülönböztethetünk az IO szemizom elégtelensége okozta A- és V-fenomént (A-fenomén: lefelé tekintéskor fokozódó divergencia; V-fenomén: felfelé tekintéskor fokozódó divergencia) [3]. Az IO szemizom túlmúködésének két formáját különböztetjük meg: a primer formában alapvetően csak az IO szemizom túlmúködését figyelhetjük meg, a szekunder forma hátterében pedig a felső ferde szemizom bénulása áll [4-6]. Ennél a típusnál már primer pozícióban látható a magassági eltérés, illetve adductióban a süllyedési deficit (1. ábra). ${ }^{1}$ Jellegzetes kényszerfejtartást mindkét forma esetén megfigyelhetünk $[4,7]$. Differenciáldiagnosztikai szempontból fontos elkülönítenünk egymástól a disszociált vertikális deviációt (DVD), a V-fenomént és más vertikális, illetve torziós kancsalságot.

Az IO szemizom a felső állcsont fossa lacrimalisáról ered és az alsó egyenes (IR) szemizmot alulról megkerülve a szem hátsó pólusán tapad (2. ábra). Primer állás-

\footnotetext{
${ }^{1}$ A fotográfiai anyagok közzétételéhez a betegek, illetve törvényes gondviselőjük írásos beleegyezésüket adták.
}

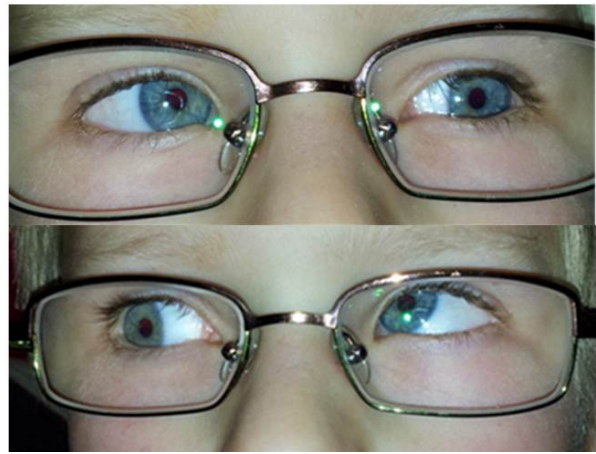

1. ábra

6 éves beteg, jobb szem: enyhe fokú IOOA, bal szem: súlyos sursoadductorius kancsalság; VD maximális adductiós helyzetben $>15^{\circ}$

IOOA = az alsó ferde szemizom túlmúködése; VD = vertikális deviáció

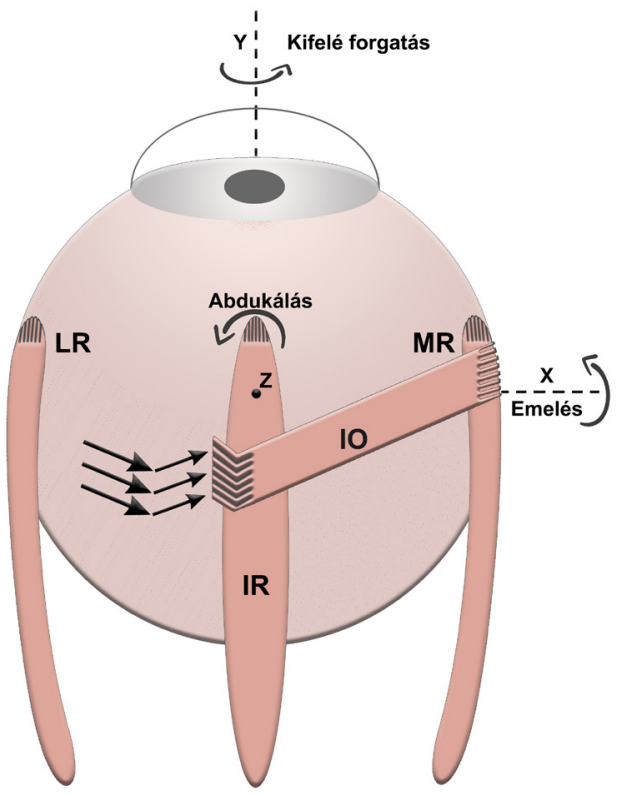

2. ábra Az IO szemizom anatómiája a jobb szemen. Az IO szemizom
hatása: excyclotorsio, emelés és abdukálás. Az IO transzpozíciót
a maximális adductióban mért VD-függvényben végeztük. Ma-
ximális transzpozíció esetén az IO szemizmot az alsó IR szem-
izom laterális széle elé helyeztük át
IO = alsó ferde; IR = alsó egyenes; VD = vertikális deviáció 
ban az IO szemizom az előrenéző szemet kifelé hengeríti, illetve kifelé és felfelé téríti úgy, hogy $51^{\circ}$-os szöget zár be az optikai tengellyel [8]. A primer típusú strabismus sursoadductorius diagnózisának feltétele a konjugált szemmozgások részletes vizsgálata, primer pozícióban elöretekintéskor a horizontális deviáció (HD) mértéke, valamint a pozitív, Bielschowsky-féle forszírozott fejbillentési teszt. Azokban az esetekben, amikor az A-, illetve V-fenoménü kancsalság fó oka az IO szemizom elégtelensége, illetve ha a beteg kettős látásról, a binokuláris látás elégtelenségéről, kényszerfejtartásról, fejfájásról, asthenopiáról és/vagy tompalátásról számol be, mútéti beavatkozás javasolt $[2,9]$.

Számos mútéti eljárás ismert az IOOA korrekciójára: ilyen az IO szemizom desinsertiója, exstirpációja, az izom denervációja, retropozíciója, myectomiája és anterior transzpozíciója [10-15]. Guemes és Wright írta le először az anterior transzpozíciós mútéti technikát [16], melynek során az IO szemizmot az IR szemizom tapadásához rögzítjük. Ehrt és Boergen írta le azt az eljárást, amelynél az IO szemizom dozírozott elülső transzpozíciója során - az IOOA súlyosságától függően - az IO szemizom tapadását az IR szemizomtól temporalisan eső területre helyezte át [9].

\section{Módszer}

Vizsgálatunk során retrospektív szemikvantitatív módszerrel elemeztük azoknak a betegeknek a mütéti eredményét, akiknél 2012. január 1-je és 2017. december 31-e között IOOA okozta sursoadductorius strabismus miatt az IO szemizom dozírozott retropozícióját végeztük a Semmelweis Egyetem Szemészeti Klinikáján. A mütétet minden betegnél egy ülésben, egy újszerü technika segítségével végeztük, melynek során az IO szemizmot gyengítettük meg. A mütétet megelőzően a betegek a legtöbb esetben kettős látásról, a binokuláris látás zavaráról, kényszerfejtartásról, krónikus fej- és gerincfájdalomról, illetve asthenopiáról panaszkodtak (3. ábra). Kizárásra kerültek azok a betegek, akiket a felső ferde szemizom paresise vagy paralízise következtében kialakult szekunder IOOA-val, illetve hegesedés következtében kialakult kancsalsággal kezeltünk. Kizárásra kerültek továbbá azok a betegek, akik korábban valamilyen szemmútéten estek át, anamnézisükben szerepelt szemsérülés, illetve akiknél ismert volt valamilyen más szembetegség, neurológiai, genetikai vagy craniofacialis rendellenesség.

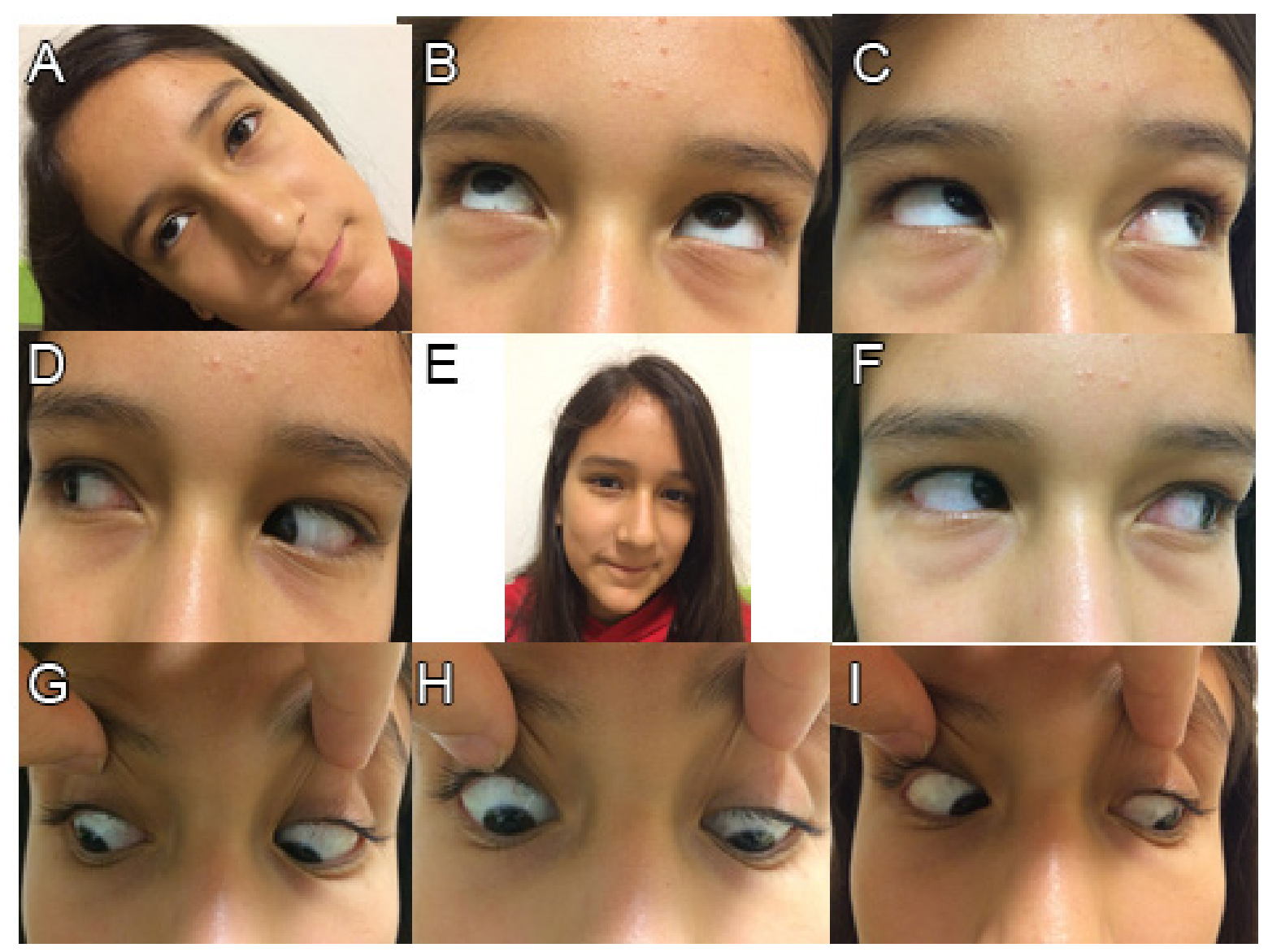

3. ábra

A preoperatív állapot rögzítése a 12 éves, IOOA-val kezelt páciensnek: kényszerfejtartás $(3 \mathrm{E})$, vertikális eltérés balra tekintéskor $\left(\mathrm{VD}<15^{\circ}\right.$ a jobb szem maximális adductiós helyzetében) (3C, 3F és $3 \mathrm{I})$

IOOA = az alsó ferde szemizom túlmúk ödése $; \mathrm{VD}$ = vertikális deviáció 


\section{Mütéti technika és követés}

A mütétek során az IO szemizmot a fornix alsó-temporalis részén, a kötőhártyán és a Tenon-tokon ejtett metszésen keresztül preparáltuk fel. Izomkampókkal leválasztottuk az elülső és a hátulsó fasciát, közben diathermia segítségével gondos vérzéscsillapítást végeztünk. Az izmot az IO izom tapadásánál választottuk le. Ezzel az újszerű technikával csökkenthetjük a felfelé tekintési korlátozottságot és az ellenoldali vertikális kancsalságot. Az IO szemizom transzpozíciója során a Guemes és mtsai [16], valamint a Boergen és mtsai [9] által leírt technikát alkalmaztuk. Ez a mütéti technika dózisfüggő összefüggést tesz lehetóvé az alsó ferde szemizom retropozíciója, valamint a maximális adductiós helyzetben elérhető eleváció között. $10^{\circ}$ alatti vertikális deviáció (VD) esetén 8 mm-es retropozíciót javasolnak, 10-15 közötti VD esetén pedig $10 \mathrm{~mm}$-es retropozíciót. Amennyiben a VD olyan nagy, hogy meghaladja a $15^{\circ}$-ot, akkor az alsó ferde szemizmot a jobb alsó egyenes szemizom tapadásához kell rögzítenünk, az említett javaslat szerint (2. ábra).

A mütét előtt meghatároztuk a betegek legjobb korrigált közeli és távoli látóélességét (BCVA), valamint részletes szemészeti és ortoptikai kivizsgáláson vettek részt.
A felfelé és a lefelé tekintés mértékét a mütét előtti, illetve a mútét utáni takarásos vizsgálat során prizmaléccel, valamint Maddox-kereszt segítségével állapítottuk meg. A mütét előtt, illetve 3 hónappal a mütét után takarásos módszerrel 5 tekintési irányban mértük meg a HD és a VD mértékét, továbbá elvégeztük a Bielschowsky-féle forszírozott fejbillentési tesztet. Lang II. teszt (200", 400", 600") és/vagy Titmus-teszt segítségével vizsgáltuk a binokuláris látást (3. ábra). A diplopiás területek feltérképezésére látótérvizsgálat nem történt (BSV - binocular single vision field).

A tervezett követési idő legalább 3 hónap volt. A betegeket természetesen - a lehetőségek szerint - a legtovább követtük, ám ez az idő nem volt egységes, tekintettel arra, hogy nem minden beteg jelent meg a Klinikán a kijelölt kontrollvizsgálaton.

\section{Statisztikai elemzés}

A statisztikai elemzéseket (varianciaanalízis, Friedmanteszt) Microsoft Excel (Microsoft Corporation, Redmond, WA, Amerikai Egyesült Államok [USA]) és Statistica 10.0 (StatSoft Inc., Tulsa, OK, USA) programok alkalmazásával végeztük el. A p<0,05 értéket tekintettük statisztikailag szignifikánsnak.

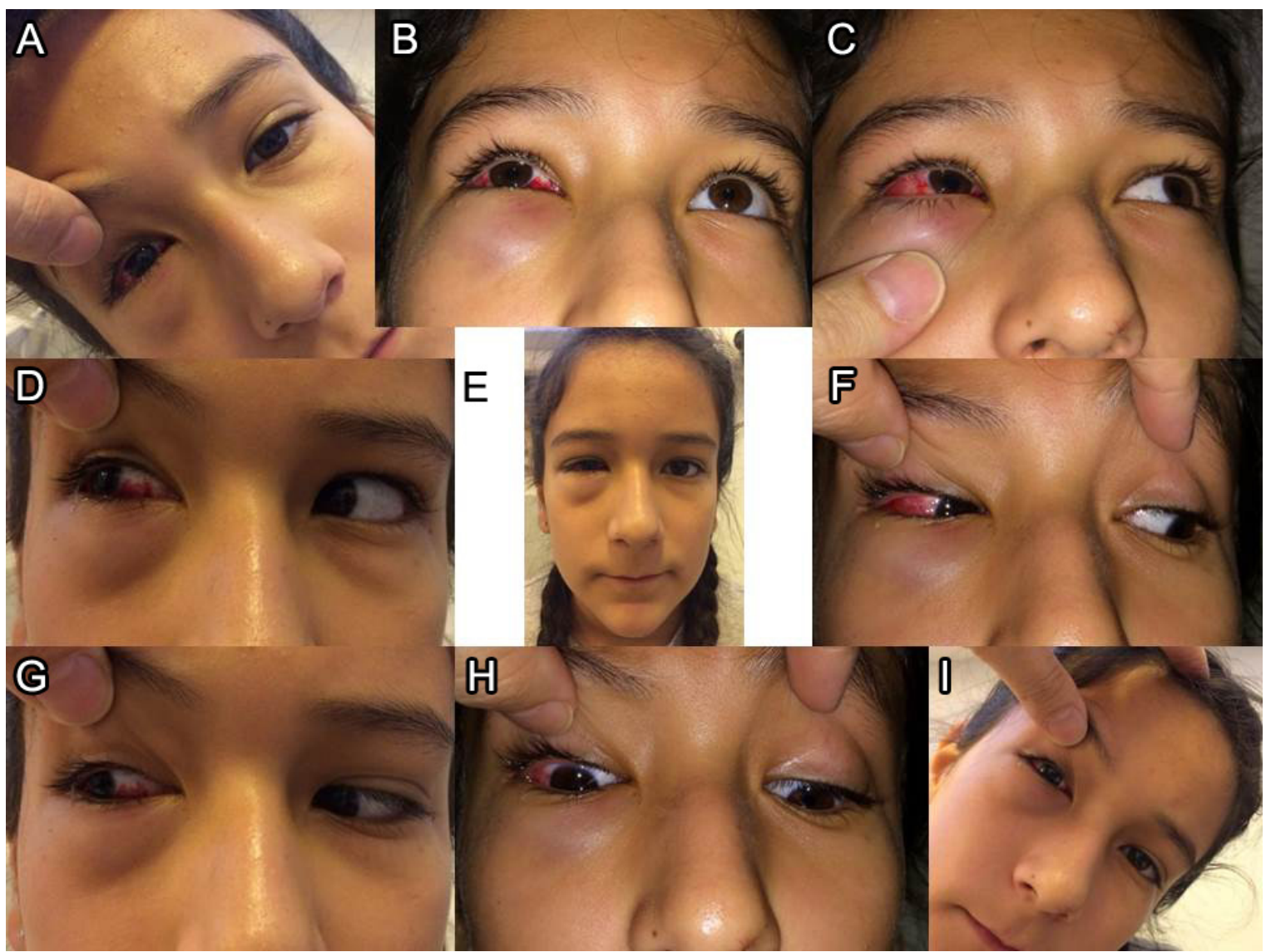

4. ábra $\quad$ Az alsó ferde szemizom maximális dozírozott recesszióját követően a bulbus állása a különböző tekintési irányokban. A kényszerfejtartás mértéke jelentősen csökkent (3E), a Bielschowsky-teszt negatív lett (3A), és vízszintesen balra tekintéskor megszúnt az alsó ferde szemizom túlmúködése (3F) 


\section{Eredmények}

A megadott 6 éves periódusban 53 beteget vizsgáltunk (24 férfi, 29 nő). Az átlagéletkor 12,8 év volt (min.max.: 2-5l év). A mütét előtti átlagos BCVA 0,86 (min.-max.: 0,3-1,0) volt, ami a mütéti beavatkozás után kismértékü, de nem szignifikáns javulást mutatott ( $>>0,05)$. A mütét utáni átlagos BCVA 0,89 (min.-max.: $0,3-1,0)$ volt. 4 beteg esetében az alacsony életkor miatt (<2 év) a BCVA nem volt felvehető, de a vizuális funkciók vizsgálata során eltérést nem találtunk. 25 beteg esetében állapítottunk meg jó binokularitást a mütét elött, a Titmus-teszt $\geq 5$, a Lang II. teszt pedig pozitív volt.

A korai posztoperatív szakban (1 hét) 12 beteg számolt be kettős látásról, ebből 1 beteg esetén állt fenn a kettős látás a mütét után 3 hónappal is. A mütét előtt 36 betegnél láttunk kényszerfejtartást, ebból 5 beteg esetén a krónikus fejfájás hátterében egyéb kóroki tényezőt nem sikerült kimutatni, illetve terápiarezisztensnek bizonyultak. A mütét előtt 45 esetben állapítottunk meg V-típusú kancsalságot, ebből 12 esetben maradt fenn a mútét után is.

A mütéteket altatásban végeztük. Súlyos intraoperatív vagy posztoperatív komplikációt egy esetben sem tapasztaltunk, a gyógyulás minden esetben eseménytelenül zajlott. Preoperatíve a maximális adductiós helyzetben mért átlagos VD 25,1 \pm 7,4 PD volt. A mütét után a magassági eltérés szignifikánsan csökkent, a mütét után 1 héttel az átlagos VD 7,3 PD $\pm 5,6(\mathrm{p}<0,01)$ volt. A mútét után 1 hónappal átlagosan 4,6 PD $\pm 5,4(\mathrm{p}<0,01)$ eltérést mértünk. Szignifikáns különbséget találtunk a mútét után 1 héttel, illetve 1 hónappal mért VD csökkenése között $(\mathrm{p}<0,01)$, és ez az állapot a mütét utáni 1-6 hónapban stabil volt $(\mathrm{p}=0,08)$ (4. és 5 ábra). 53 beteg esetében az átlagosan mért VD csökkenése 21 PD volt $\left(10,5^{\circ}\right)$. A mútét előtt látott kényszerfejtartás 10 esetben maradt fenn a mútét után is, viszont a krónikus fejfájásos panaszok minden esetben jelentősen enyhültek a posztoperatív időszakban. Azoknál a betegeknél, akiket a mütét után hosszabb ideig követtünk, nem tapasztaltunk komoly szövődményt, újbóli mütét nem volt szükséges.

\section{Megbeszélés}

A kétezres évektől napjainkig számos olyan tanulmány jelent meg, amely az IOOA és a V-típusú kancsalság dozírozott és anterior transzpozíciójának eredményességével és megbízhatóságával foglalkozik $[2,3,9,16,17]$. Számos, az izom gyengítésével járó mútéti technika mint az IO szemizom tenotomiája [10], hátulsó transzpozíciója és anteriorizációja, myectomiája, desinsertiója, illetve denervációja - bár régóta ismert kezelési eljárása a felső ferde (SO) szemizom bénulásának [15, 18, 19], hatékonyságuk a mai napig vitatott.

A myectomia általában rövid és egyszerű eljárás. A retropozíció, illetve az IO szemizom anterior és nasalis transzpozíciója azonban már nagyobb kihívást és hosz-

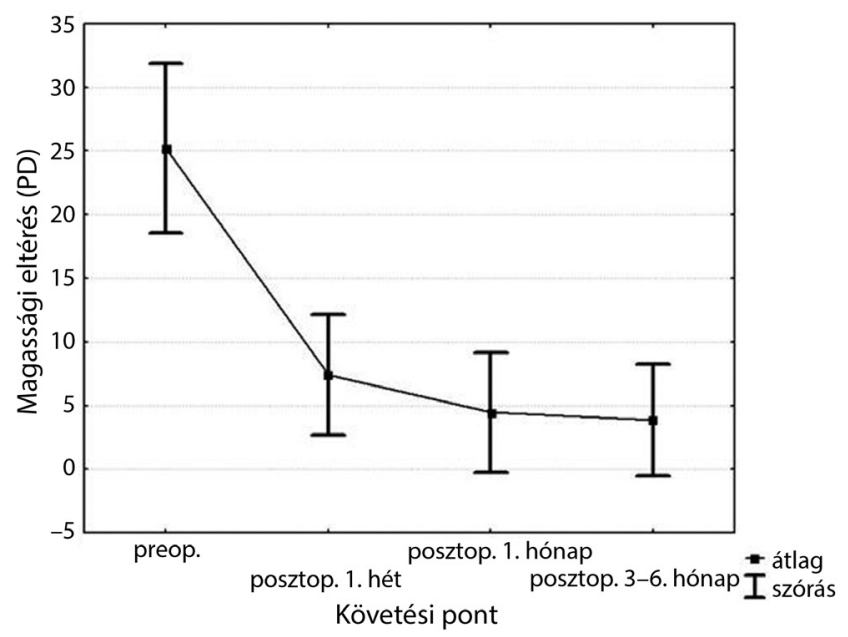

5. ábra

$$
\begin{aligned}
& \text { Az IO szemizom dozírozott transzpozíciója előtti, illetve a mú- } \\
& \text { tét után mért magassági eltérés mértéke } \\
& \text { IO = alsó ferde }
\end{aligned}
$$

szabb mútéti eljárást jelent. Bizonyos anatómiai eltérések, mint például a kétfejű IO szemizom ina, nehézséget jelenthetnek a mütét során. Az IO szemizom anterior és nasalis transzpozíciója egyre inkább hatékonynak bizonyul a súlyos, illetve iatrogén SO szemizom bénulásának és a disszociált vertikális deviációval járó (DVD) nagyfokú IO szemizom súlyos bénulásának kezelésében $[5,6$, $20]$.

Tanulmányunk során az alsó ferde szemizom 53 esetben - Magyarországon elsóként - végzett dozírozott transzpozíciójának eredményességét vizsgáltuk. Minden betegnél úgynevezett primer típusú IOOA-t állapítottunk meg; a nervus trochlearis következtében kialakult szekunder típusú IOOA-val rendelkező betegek kizárásra kerültek a vizsgálatból. Az általunk vizsgált 53 betegnél nem tapasztaltuk az IO szemizom perzisztáló túlmúködését. Minden esetben sikerült csökkentenünk a VD mértékét, illetve más klinikai tünetet, mint a kényszerfejtartást és a krónikus fejfájásos panaszokat. Irodalmi adatok alapján az IO szemizom mútéte során - a sebészi eljárástól függetlenül - tapasztalt leggyakoribb szövődmény a perzisztáló vagy rekurráló izomtúlmúködés [3]. A mütétet követően is fennálló izomtúlmúködés leggyakoribb oka az IO szemizom nem tökéletes izolációja, melynek során a hátsó izomrostok intaktak maradtak. Az IO szemizom mútétének további szövődménye lehet az orbita elülső részén keletkező vérzés, pupilladilatáció, a laterális egyenes szemizom károsodása, iatrogén sérülése és a maculatájat érintő sérülés következtében kialakult látásvesztés [16].

A korai posztoperatív időszakban 12 beteg számolt be kettős látásról, amely 1 beteg kivételével, a mútét után 3 hónappal megszűnt. A mütétet követő 3 hónapban mindössze 3 beteg számolt be átmeneti excyclodiplopiáról. Egyéb súlyos szövődményt - mint például endophthalmitist, orbitalis cellulitist, illetve orbitalis kompart- 
ment szindrómát - nem tapasztaltunk. Jelentős visszaesést, illetve késői szövődményt egy esetben sem tapasztaltunk, a késői posztoperatív időszakban sem.

\section{Következtetés}

Az IO szemizom dozírozott transzpozíciója hatékony mütéti eljárásnak bizonyult a strabismus sursoadductorius kezelésében. A funkcionális alulkorrigálás aránya és az altatás következtében kialakuló szövődmények gyakorisága, illetve a mütét következtében kialakult felfelé tekintési korlátozottság alacsony.

Anyagi támogatás: A közlemény megírása, illetve az ehhez kapcsolódó kutatómunka anyagi támogatásban nem részesült.

Szerzői munkamegosztás: M. O. A.: A betegek kezelése (kancsalságellenes mütét, vizsgálat), az adatok és az eredmények feldolgozása, irodalomkutatás és a kézirat megírása. K. K.: A betegek sebészi ellátása, asszisztálás, nyelvi lektorálás. M. E.: Folyamatos szakmai felügyelet, az irodalom áttekintése és részvétel a cikk tartalmi javításában. B. F., S. G.: A cikk tartalmi javítása és adatfeldolgozás. N. Z. Zs.: A kézirat tartalmi korrekciójában, szerkesztésében és a megbeszélés fejezetének megírásában nyújtott segítséget. A cikk végleges változatát valamenynyi szerző elolvasta és jóváhagyta.

Érdekeltségek: A szerzőknek nincsenek érdekeltségeik.

\section{Irodalom}

[1] Choi DG, Chang BL. Electron microscopic study on overacting inferior oblique muscles. Korean J Ophthalmol. 1992; 6: 69-75.

[2] Caldeira JA. Some clinical characteristics of V-pattern exotropia and surgical outcome after bilateral recession of the inferior oblique muscle: a retrospective study of 22 consecutive patients and a comparison with V-pattern esotropia. Binocul Vis Strabismus Q. 2004; 19: 139-150.

[3] Caldeira JA. V-pattern esotropia: a review; and a study of the outcome after bilateral recession of the inferior oblique muscle: a retrospective study of 78 consecutive patients. Binocul Vis Strabismus Q. 2003; 18: 35-48.

[4] von Noorden GK, Murray E, Wong SY. Superior oblique paralysis. A review of 270 cases. Arch Ophthalmol. 1986; 104: 17711776 .

[5] Ehrt O, Boergen KP. A concept for the surgical treatment of trochlear palsy. Strabismus 2004; 12: 75-83.

[6] Lee DC, Lee SY. Effect of modified graded recession and anteriorization on unilateral superior oblique palsy: a retrospective study. BMC Ophthalmol. 2017; 17: 27.

[7] Parks MM. The overacting inferior oblique muscle. The XXXVI Deschweinitz Lecture. Am J Ophthalmol. 1974; 77: 787-797.

[8] Basic and Clinical Science Course. Section 6: Pediatric Ophthalmology and Strabismus. American Academy of Ophthalmology, San Francisco, CA, 2010.

[9] Ehrt O, Bekl Y, Boergen KP. Effect of inferior oblique recession in strabismus sursoadductorius. Strabismus 2002; 10: 63-68.

[10] Duane A. Tenotomy of inferior oblique and consideration of the conditions that may call for the operation. Br Med J. 1906; 2: $1867-1870$.

[11] Costenbader FD, Kertesz E. Relaxing procedures of the inferior oblique; a comparative study. Am J Ophthalmol. 1964; 57: 276280.

[12] Apt L, Call NB. Inferior oblique muscle recession. Am J Ophthalmol. 1978; 85: 95-100.

[13] Elliott RL, Nankin SJ. Anterior transposition of the inferior oblique. J Pediatr Ophthalmol Strabismus 1981; 18: 35-38.

[14] Parks MM. Inferior oblique weakening procedures. Int Ophthalmol Clin. 1985; 25: 107-117.

[15] Cho YA. Treatment of marked overaction of inferior oblique: denervation and extirpation of inferior oblique. J Korean Ophthalmol Soc. 1987; 28: 381-386.

[16] Guemes A, Wright KW. Effect of graded anterior transposition of the inferior oblique muscle on versions and vertical deviation in primary position. J AAPOS 1998; 2: 201-206.

[17] Minguini N, de Carvalho KM, de Araújo L, et al. Anterior transposition compared to graded recession of the inferior oblique muscle for V-pattern strabismus. Strabismus 2004; 12: 221-225.

[18] Gonzalez C. Denervation of the inferior oblique: current status and long-term results. Trans Sect Ophthalmol Am Acad Ophthalmol Otolaryngol. 1976; 81: 899-906.

[19] Helveston EM, Haldi BA. Surgical weakening of the inferior oblique. Int Ophthalmol Clin. 1976; 16: 113-126.

[20] Burke JP, Scott WE, Kutshke PJ. Anterior transposition of the inferior oblique muscle for dissociated vertical deviation. Ophthalmology 1993; 100: 245-250.

(Maneschg Otto dr.,

Budapest, Mária u. 39., 1085

e-mail: maneschg.otto@med.semmelweis-univ.hu)

A cikk a Creative Commons Attribution 4.0 International License (https://creativecommons.org/licenses/by/4.0/) feltételei szerint publikált Open Access közlemény, melynek szellemében a cikk bármilyen médiumban szabadon felhasználható, megosztható és újraközölhető, feltéve, hogy az eredeti szerző és a közlés helye, illetve a CC License linkje és az esetlegesen végrehajtott módosítások feltüntetésre kerülnek. (SID_1) 